\title{
Influence of the technical operation of passenger road transport on the quality indicators of transportation in interregional traffic
}

\author{
Vyacheslav Epifanov ${ }^{1}$, Michael Obshivalkin ${ }^{1}$, and Kristina Generalova ${ }^{1 *}$ \\ ${ }^{1}$ Ulyanovsk State Technical University, Severny Venets Street, 32, Ulyanovsk, Russia
}

\begin{abstract}
In order to improve transport services for the population, it is necessary, based on the accumulated experience and wishes of passengers, to carefully study and analyze information on the quality of transport services. This requires the development of modern methods that will effectively improve the level of transport activities. The main prerequisites will be the development of methodological regulations for the organization of the transport process, which will primarily relate to improving its quality and safety. The article establishes the relationship of factors affecting the efficiency of technical operation of the vehicle, which in turn affects the quality indicators of inter-municipal passenger traffic. Quality scores are considered simple to calculate and easy to use; Quality indicators are formed in such a way that they can be used to judge the activities of carriers in the field of improving the quality of the transport process and, thus, to separate the quality aspects that depend and do not depend on their activities. The article uses indicators developed on the basis of the requirements of quality standards for transport services. Such an approach in the process of managing passenger traffic in intermunicipal traffic can greatly contribute to improving the quality of service to the population by intermunicipal road transport. The analysis made it possible to establish modern features of the functioning of passenger traffic in intermunicipal traffic and outline ways to improve the quality of transportation and the efficiency of passenger road transport, of which, first of all, one can single out: increasing the efficiency of using road transport, reducing transport costs, developing the production and technical base. and maintenance and repair technologies.
\end{abstract}

A whole range of related activities is aimed at improving the quality of passenger transportation by inter-municipal road transport. To develop such measures, it is necessary, based on the accumulated experience and passenger satisfaction, to study and analyze information on the quality of transport services.

The work of transport depends to a greater extent on the needs of the consumer in his services, and the consumer is not so much interested in the costs of carriers for service. He is attracted by the minimum travel time, one hundred percent guarantee of the trip, the safety and convenience of the trip, the ability to obtain reliable information about travel, the

* Corresponding author: tinetta.ledi@mail.ru 
convenient location of bus stations and the like. The passenger is ready to bear certain costs only under these conditions $[1,2]$.

The aim of the study is to improve the quality of passenger transportation by intermunicipal road transport by increasing the efficiency of technical operation of passenger road transport.

The main task is to stabilize the situation on the market of regular passenger traffic on inter-municipal routes. The solution to this problem on the routes will be the development of an integral management system, which is focused on the population, on the quality satisfaction of their needs, and a decrease in socially necessary costs for transportation.

The creation of comfortable conditions for the transportation of passengers by intermunicipal passenger road transport (I-MPRT) depends on the quality of solving goals and objectives at all stages of the transportation life cycle.

The MPAT transportation system implements a certain set (set) of goals:

$$
Ц=\left\{Ц_{1}, \ldots, Ц_{i}, \ldots, Ц_{n}\right\},
$$

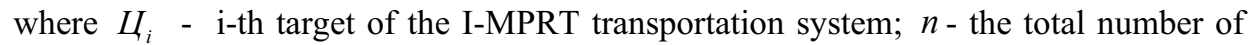
targets.

When forming a set of factors of the MPAT transportation system that affect the efficiency of technical operation of vehicles (TOV), it is necessary to solve the problem of creating an optimal set of them, which are the most informative for solving the goals of improving the quality of transportation [3].

Quality indicators $A_{\kappa}$ in order to ensure and improve their quality, they are evaluated by transportation factors $K_{\ni}$. In turn, indicators of the quality of transportation $A_{\kappa}$ largely depend on the implementation of indicators of technical operation of vehicles $T_{a}$, affecting TOV indicators.

In this case, we can assume that the elements of the set of factors of the I-MPRT transportation system enter into binary relations with the elements of the sets $A_{\kappa}$ quality indicators and $T_{a}$ technical operation of cars, which establish the correspondence of the elements of one set to the elements of another. Set relations $A_{\kappa}, K_{\ni}$ и $T_{a}$ can be shown using a directed graph (Fig. 1).

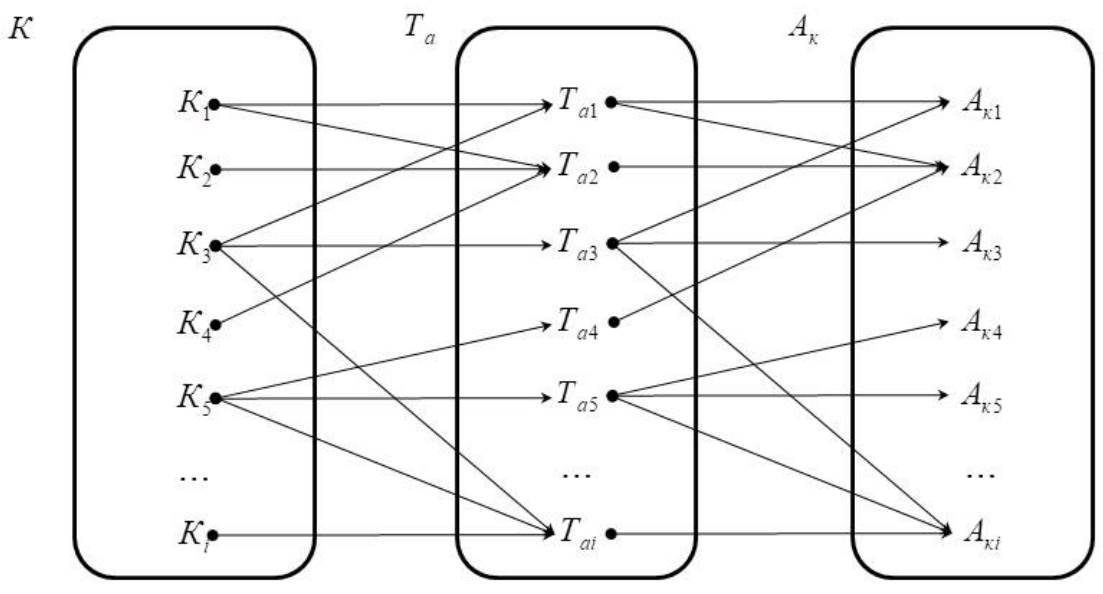

Fig. 1. Relationship graph $K_{\ni}, A_{\kappa}, T_{a}$ 
TOV indicators largely depend on factors. In road transport activities, the operation of cars solves the problems of transporting passengers, maintaining the fleet in a working condition and its material and technical support (technical operation). In this case, the task of TOV is to provide transportation activities with efficient and technically sound vehicles, that is, to ensure the possibility of implementing the transport process.

Consequently, the initial direction in increasing the efficiency of operation in road transport activities is the possibility of increasing the degree of technical readiness of the rolling stock to perform transport work at the lowest cost. Thus, further analysis of the factors affecting the efficiency of vehicle operation was carried out from the position of TOV, which includes a set of means, methods and methods of human activity aimed at efficient use and quality assurance of passenger transportation in intermunicipal traffic, in terms of safety, comfort, reliability, availability, timeliness, efficiency and comfort at bus stations and bus stations.

Goals, quality indicators, TOV indicators and factors are provided and implemented by certain economic entities, that is, enterprises, organizations, departments $O_{c}$ (Fig. 2).

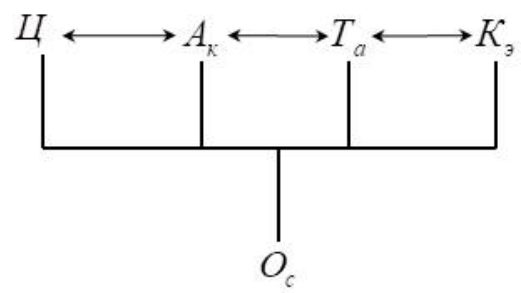

Fig. 2. The relationship between the elements of intermunicipal transportation

Each purpose of transportation is implemented by certain economic entities (transport, organizational and managerial enterprises and organizations, etc.). Any goal is provided by a complex of transportation tasks, which in turn is implemented by economic entities (Table 1), where each economic entity implements several tasks in the transportation process [4].

Let's formulate the goals of the I-MPRT transportation system:

1) Plan the transportation of passengers in inter-municipal traffic;

2) Plan to improve the quality of passenger transportation in inter-municipal traffic;

3) Provide transportation resources in I-MPRT;

4) Carry out the transport process of transportation in intermunicipal traffic;

5) Provide monitoring and regulation of traffic in intermunicipal traffic;

6) Constantly improve the quality of transportations in inter-municipal traffic.

Table 1. Relationship between MPAT goals and quality indicators

\begin{tabular}{|c|c|c|}
\hline $\begin{array}{l}\text { Purpose of } \\
\text { transportation }\end{array}$ & Tasks & $\begin{array}{c}\text { Transport quality indicator } \\
A_{i}\end{array}$ \\
\hline $\begin{array}{l}\text { Plan the } \\
\text { transportation of } \\
\text { passengers in } \\
\text { inter-municipal } \\
\text { traffic; }\end{array}$ & $\begin{array}{l}\text { 1) Analysis of passenger traffic in } \\
\text { inter-municipal traffic; } \\
\text { 2) Clarification of the route network } \\
\text { of intermunicipal transport links; } \\
\text { 3) Conducting a competitive } \\
\text { selection of applicants for the } \\
\text { right to carry passengers; } \\
\text { 4) Development of a timetable for } \\
\text { the movement of buses along the } \\
\text { route network. }\end{array}$ & $\begin{array}{l}A_{2} \text { - Reliability of } \\
\text { transport services (stability } \\
\text { in receiving services, } \\
\text { predictability of the level } \\
\text { of their quality); } \\
A_{3} \text { - Timeliness of } \\
\text { passenger transportation }\end{array}$ \\
\hline
\end{tabular}


Continuation of table 1

\begin{tabular}{|c|c|c|}
\hline $\begin{array}{l}\text { Purpose of } \\
\text { transportation }\end{array}$ & Tasks & $\begin{array}{c}\text { Transport quality indicator } \\
A_{i}\end{array}$ \\
\hline $\begin{array}{l}\text { Plan to improve } \\
\text { the quality of } \\
\text { passenger } \\
\text { transportation in } \\
\text { inter-municipal } \\
\text { traffic; }\end{array}$ & $\begin{array}{l}\text { 1) Development of a methodology } \\
\text { for assessing passenger } \\
\text { satisfaction with the quality of } \\
\text { transport services; } \\
\text { 2) Analysis of customer (passenger) } \\
\text { satisfaction with the quality of } \\
\text { services provided; } \\
\text { 3) Ensuring the required level of } \\
\text { preparedness of business entities } \\
\text { to carry out transportation; } \\
\text { 4) Substantiation of indicators of the } \\
\text { quality of passenger } \\
\text { transportation in intermunicipal } \\
\text { traffic; } \\
\text { 5) Approval of documented } \\
\text { procedures for carrying out } \\
\text { transportations with planned } \\
\text { quality. }\end{array}$ & $\begin{array}{l}A_{4} \text { - Comfort of } \\
\text { transportation of } \\
\text { passengers (level of ease } \\
\text { of use of services); } \\
A_{6} \text { - Information content } \\
\text { (information service); } \\
A_{14} \text { - Serving passengers at } \\
\text { bus stations and bus } \\
\text { stations (time for } \\
\text { purchasing tickets and the } \\
\text { list of services provided) }\end{array}$ \\
\hline $\begin{array}{l}\text { Provide } \\
\text { transportation } \\
\text { resources in I- } \\
\text { MPRT; }\end{array}$ & $\begin{array}{l}\text { 1) Provision with material, human, } \\
\text { financial resources; } \\
\text { 2) Improvement of the transport } \\
\text { infrastructure in intermunicipal } \\
\text { traffic; } \\
\text { 3) Ensuring the required level of } \\
\text { preparedness of business entities } \\
\text { to carry out transportation. }\end{array}$ & $\begin{array}{l}A_{2} \text { - Reliability of } \\
\text { transport services (stability } \\
\text { in receiving services, } \\
\text { predictability of the level } \\
\text { of their quality); } \\
A_{3} \text { - Timeliness of } \\
\text { passenger transportation; } \\
A_{5} \text { - Service profitability } \\
\text { (cost indicator) }\end{array}$ \\
\hline $\begin{array}{l}\text { Carry out the } \\
\text { transport process } \\
\text { of transportation } \\
\text { in intermunicipal } \\
\text { traffic; }\end{array}$ & $\begin{array}{l}\text { 1) Clarification of the timetable for } \\
\text { inter-municipal transport links; } \\
\text { 2) Ensuring the conformity of } \\
\text { transportation routes to } \\
\text { categories, classes, capacity and } \\
\text { other technical characteristics of } \\
\text { vehicles; } \\
\text { 3) Management of logistics of inter- } \\
\text { municipal transport } \\
\text { communication based on } \\
\text { dispatching. }\end{array}$ & $\begin{array}{l}A_{1} \text { - Safety of passenger } \\
\text { transportation services; } \\
A_{2} \text { - Reliability of } \\
\text { transport services (stability } \\
\text { in receiving services, } \\
\text { predictability of the level } \\
\text { of their quality); } \\
A_{3} \text { - Timeliness of } \\
\text { passenger transportation; } \\
A_{5} \text { - Service profitability } \\
\text { (cost indicator) }\end{array}$ \\
\hline
\end{tabular}

The quality indicator, when moving passengers on inter-municipal transport, is a quantitative characteristic of one of the features that make up the quality of passenger traffic, considered in relation to certain conditions of their organization and implementation [5]. Most authors equate the quality of passenger transportation with safety [6 - 8]. In fact, safety requirements for transportation are reflected in all standards related to passenger 
transport services [9 - 11]. The indicators that help to assess the quality of transportation include travel safety, travel time, comfort of travel and waiting, etc.

An expert assessment of more significant indicators of the quality of passenger transportation showed the following distribution: the safety of passenger transportation services $\left(A_{1}-13,2 \%\right)$; reliability of transport service $\left(A_{2}-12,7 \%\right)$; timeliness of passenger transportation ( $\left.A_{3}-10,9 \%\right)$; comfort of passenger transportation $\left(A_{4}-11,8 \%\right)$; profitability of the service $\left(A_{5}-9,4 \%\right)$; informativeness $\left(A_{6}-8,7 \%\right)$; comfort of passengers at bus stations and bus stations $\left(A_{14}-9 \%\right)$. Of the 14 indicators, 7 were identified as the most significant. They accounted for $80 \%$ of the total number of indicators.

As part of the implementation of the process of the current level of passenger satisfaction, it is necessary to calculate a comprehensive indicator of the level of quality of transport services for passenger transportation in the Ulyanovsk region.

Complex indicator $A_{u}$ the level of quality of transport services for passenger traffic is defined as follows:

$$
A_{u}=\sum_{i=1}^{M} A_{i} q_{i з н},
$$

where $A_{i}$ - the value of the most significant indicators used to assess the quality of transport services; $q_{і з н}$ - coefficient characterizing the weight of significant quality indicators; $m$ - the number of quality indicators assessed.

We propose to determine the numerical value of each indicator of the quality of transport services included in the final indicator through the highlighted answers of passengers to the questionnaire. In this case, the numerical value of each quality indicator is determined as the average value of the numerical values of the answers in shares for several questions of the questionnaire (Table 2).

Table 2. Numerical values of the parameters of the quality of transport services.

\begin{tabular}{|l|c|}
\hline \multicolumn{1}{|c|}{$\begin{array}{c}\text { Average value of the indicator of the quality of transport } \\
\text { services }\end{array}$} & $\begin{array}{c}\text { Quality } \\
\text { indicator value in } \\
\text { shares }\end{array}$ \\
\hline 1. Safety of passenger transportation services & 0,68 \\
2. Reliability of service in transport & 0,7 \\
3. Comfort of transportation of passengers & 0,53 \\
4 Timeliness of passenger transportation & 0,76 \\
5. Economy of the service & 0,68 \\
6. Informativeness & 0,6 \\
7. Comfort of passengers at bus stations and bus stations & 0,77 \\
\hline
\end{tabular}

Thus, the numerical values of each indicator of the quality of transport services for the transportation of passengers in the interregional traffic of the Ulyanovsk region have been determined. Table 2 shows that all quality indicators require significant improvement.

The analysis [12] of the current state of passenger carriage by road transport in intermunicipal traffic allowed us to identify the reasons and the corresponding factors that reduce or increase the efficiency of the technical operation of passenger road transport. To systematize the factors affecting the efficiency of technical operation and quality indicators of transportation, a summary table has been developed (Table 3). 
Thus, from the table, it can be seen that the sphere of operation affects the quality indicators of transportation, improving methods and means of ensuring efficiency, qualification of personnel, adjusting the age composition of the fleet and other methods.

The technical operation of cars is the most important subsystem of road transport, it gives an actual opportunity, supplying serviceable cars for the transportation process. Technical operation as a subsystem of road transport should contribute to the implementation of the goals of road transport and have controllable indicators of the quality of TOV, linked to the quality indicators of transport in intermunicipal traffic.

Table 3. Influence of TOV on the quality indicators of transportation.

\begin{tabular}{|c|c|c|}
\hline $\begin{array}{l}\text { Factors affecting the } \\
\text { effectiveness of TOV } \\
K_{\text {э }}\end{array}$ & $\begin{array}{l}\text { TOV indicators } \\
\qquad T_{a}\end{array}$ & $\begin{array}{l}\text { Quality indicators } \\
\qquad A_{i}\end{array}$ \\
\hline \multirow{6}{*}{$\begin{array}{l}\text { 1) PTB: } \\
\text { - State of PTB } \\
\text { - Level of cooperation } \\
\text { and specialization of } \\
\text { PTB } \\
\text { 2) Personnel: } \\
\text { - Provision of qualified } \\
\text { personnel } \\
\text { 3) Park structure, } \\
\text { spare parts and } \\
\text { materials: } \\
\text { - The level of reliability } \\
\text { of buses } \\
\text { - PS structure } \\
\text { - Logistics of spare parts } \\
\text { and materials. } \\
\text { 4) Operating } \\
\text { conditions: } \\
\text { - Quality of roads } \\
\text { - Road condition } \\
\text { - Traffic intensity. }\end{array}$} & $\begin{array}{c}\text { - Ratio of technical } \\
\text { readiness }\end{array}$ & $\begin{array}{l}A_{1} \text { Service security } \\
A_{2} \text { Reliability } \\
A_{4} \text { Comfort of transportation } \\
A_{3} \text { Timeliness of transportation } \\
A_{5} \text { Service efficiency } \\
A_{6} \text { Informativeness } \\
A_{14} \text { Serving passengers at bus } \\
\text { stations and bus stations }\end{array}$ \\
\hline & - $\mathrm{MTBF}$ & $\begin{array}{l}A_{1} \text { Service security } \\
A_{2} \text { Reliability }\end{array}$ \\
\hline & 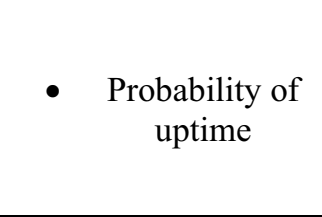 & $\begin{array}{l}A_{1} \text { Service security } \\
A_{2} \text { Reliability } \\
A_{3} \text { Timeliness of transportation } \\
A_{6} \text { Informativeness }\end{array}$ \\
\hline & $\begin{array}{c}\text { Resource before } \\
\text { overhaul and } \\
\text { write-off }\end{array}$ & $\begin{array}{l}A_{1} \text { Service security } \\
A_{2} \text { Reliability } \\
A_{5} \text { Service efficiency }\end{array}$ \\
\hline & $\begin{array}{l}\text { - Downtime for } \\
\text { maintenance and } \\
\text { repair }\end{array}$ & $\begin{array}{l}A_{2} \text { Reliability } \\
A_{3} \text { Timeliness of transportation } \\
A_{5} \text { Service efficiency }\end{array}$ \\
\hline & - Cost of operation & $\begin{array}{l}A_{1} \text { Service security } \\
A_{2} \text { Reliability } \\
A_{3} \text { Timeliness of transportation } \\
A_{5} \text { Service efficiency } \\
A_{6} \text { Informativeness }\end{array}$ \\
\hline
\end{tabular}

All these factors $K_{\text {, }}$ affect TOV indicators $T_{a}$ and, in turn, changing the indicators of the quality of transportation (Table 3). Transportation safety will increase due to the improvement of the bus maintenance and repair system, due observance of the regulatory 
framework, the use of new and modern systems, and the improvement of the maintenance of the road traffic system. The reliability and timeliness of transportation will increase by reducing failures and downtime in maintenance and repair. The comfort of transportation will be influenced by the compliance of inter-municipal transportation with all requirements and standards, compliance with the cleanliness of the rolling stock during daily inspection and maintenance of the bus interior in proper condition. All TOV indicators influence the efficiency of transportation. Since any deviation from the standards, downtime, going off the line, purchasing new materials, etc. incur financial losses.

In the course of the work, modern features of the functioning of passenger transportation in intermunicipal traffic were established and ways were outlined to improve the quality of transportation and the efficiency of operation of passenger road transport, of which one can single out: increasing the efficiency of using road transport, reducing transportation costs, developing the production and technical base and technology. Maintenance and repair [13-14].

\section{References}

1. V.A. Gudkov, A.B. Mirotin, A.V. Velmozhin, S.A. Shiryaev; Passenger road transport: a textbook for universities, Hot line - Telecom, P. 448 (2004)

2. I.O. Zagorskiy, P.P. Volodkin, Efficiency of organizing regular transportation by passenger motor transport, Monograph, Pacific Publishing House, P. 154 (2012)

3. A.A. Zykov, Fundamentals of graph theory. Science, P. 384 (1987)

4. L.P. Sullivan, “Quality Funktion Deployment”, Quality Progress, pp. $39-50$ (1986)

5. L.M. Kieu, A. Bhaskar, E. Chung, Public Transport Travel-Time Variability Definitions and Monitoring, Jornal of Transportation Engineering. №7. pp. 122-130. (2014)

6. X. Zou,, W.L Yue,. A Bayesian Network Approach to Causation Analysis of Road Accidents Using Netica, Journal of Advanced Transportation, (2017)

7. Z. Cai,, D.Wang,, X.M. Chen, A novel trip coverage index for transit accessibility assessment using mobile phone data, Journal of Advanced Transportation, (2017)

8. GOST R 51825-2001 "Passenger road transport services. General requirements". Gosstandart of Russia, 8 p. (2001)

9. GOST R 51004-96 "Transport services. Passenger Transportation. Nomenclature of quality indicators ". Gosstandart of Russia, 15 p. (1996)

10. GOST R 51006-96 Transport services. Terms and Definitions. Gosstandart of Russia, 12 p. (1996)

11. K.A. Generalova, Analysis of quality assurance of passenger road transport in interregional and interdistrict communications, At 3 o'clock Part 1, 84 -87 (2019)

12. V.N. Saleev, To improve the quality of service to the population, Freight and passenger motor transport. No. 12. pp. 40 - 42 (2006)

13. Z. Cai,, D.Wang, X.M. Chen, Adaptive Rolling Smoothing With Heterogeneous Data for Traffic State Estimation and Prediction, IEEE transactions on intelligent transportation systems, (2013)

14. N.Kh. Man, A.N. Rementsov, Improving the efficiency of the functioning of passenger motor transport enterprises in Hanoi, No. 8. pp. 34 - 39. (2014) 